
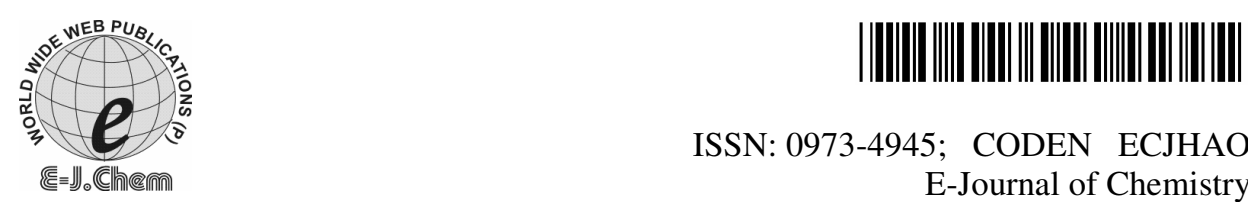

ISSN: 0973-4945; CODEN ECJHAO

http://www.e-journals.net

E-Journal of Chemistry

2009, 6(2), 412-418

\title{
Effects on Setting, Strength, Moisture Resistance and Linear Changes of Sorel's Cement on Mixing Portland Cement as an Additive
}

\author{
RITU MATHUR, M.P.S. CHANDRAWAT ${ }^{\#}$ and SANJAY K. SHARMA* \\ Department of Chemistry, R.R. College, Alwar, India. \\ \#IET Biotechnology Institute, MIA, Alwar, India. \\ *Department of Chemistry, \\ Institute of Engineering \& Technology, MIA, Alwar, India. \\ drsanjay_iet@yahoo.co.in
}

Received 4 September 2008; Revised 17 October 2008; Accepted 1 November 2008

\begin{abstract}
Magnesium oxysulphate cement (MOC, Magnesia / Sorel's Cement), discovered by Sorel S.T. in 1867 and has versatile cementing characteristics. It is prepared by the reaction of magnesium sulphate with magnesia in aqueous solution. Dolomite is used as inert filler to absorb the heat evolved during the exothermic formations of oxysulphate cement. Additives play an important role to modify the properties of Sorel's cement by nullifying the harmful effects of the impurities present in the matrix. Incorporation of Portland cement in increasing quantities in magnesium oxysulphate cement improves the compressive strength of the cement remarkably. Water tightness of Sorel's cement increases with the increase in quantities of the additive $(15 \%, 20 \%)$. Portland cement accelerates initial setting process and retards final setting process of oxysulpahte cement. An insignificant contraction in the length of the trial beams after mixing Portland cement in oxysulphate cement was an encouraging finding of the study.
\end{abstract}

Keywords: Portland cement, Magnesium oxysulphate cement, Compressive strength, Weathering effect and Linear changes.

\section{Introduction}

Some materials can be exploited directly or indirectly for fastening, adhering or binding substances. These are called chemical binders. This behavior is attributable to their polymerization tendencies or interlocking crystal habits ${ }^{1}$. A French scientist Sorel S.T. in 1867 discovered magnesium oxysulphate/oxychloride Cement ${ }^{2-9}$. It has versatile cementing properties, superior to those of Portland cement ${ }^{10,11}$. The structure of magnesium oxychloride 
cements has been studied by Tooper and Cartz and its figure was taken with a scanning electron microscope $\mathrm{e}^{12}$

Magnesium oxysulphate cement (MOC) of $5 \mathrm{mg}(\mathrm{OH})_{2} \cdot \mathrm{MgSO}_{4} \cdot 8 \mathrm{H}_{2} \mathrm{O}$ composition is most commonly found ${ }^{13}$. Plain oxysulphate cement is a weak binder than oxychloride cement, but the nature of the raw materials, their proportions, workmanship, conditions of curing (low temperature and high humidity), post curing measures and maintenance add to ultimate strength and durability of the product ${ }^{14-17}$. Additives or admixtures also play important role to modify the properties of oxysulphate cement and nullify the pernicious effects of the impurities present in the raw materials and thus make the product sound. Changes in properties of magnesium oxysulphate cement on admixing sodium bicarbonate as an additive have been studied separately, which reveals that sodium bicarbonate increases setting periods in all proportions within the experimental limits. It also improves the water tightness and strength of the cement when is added in powdered form. But in the form of saturated solution sodium bicarbonate is not a good additive ${ }^{18}$.

In this study, Portland cement is tried as an additive to improve the quality of magnesium oxysulphate cement. Effect of Portland cement on setting characteristics of magnesium oxysulphate cement was studied by incorporating it in different amounts in the dry mix (1:2 dry mix was prepared by weight of magnesia and dolomite), on the basis of: (i) setting time investigations, (ii) weathering effects, (iii) moisture ingress (Steam tests), (iv) compressive strength tests and (v) linear changes (for soundness). The results are reported in the present article.

Portland cement is essentially a mixture of calcium silicates and calcium aluminates with small quantities of silica $\mathrm{SiO}_{2}(20-25 \%)$, aluminium oxide $\mathrm{Al}_{2} \mathrm{O}_{3}(5-10 \%)$, magnesium oxide $\mathrm{MgO}(2-3 \%)$, ferric oxide $\mathrm{Fe}_{2} \mathrm{O}_{3}$ (1-2\%) and sulphur trioxide $\mathrm{SO}_{3}$ (1-3\%) etc. It is prepared by limestone and clay. Its three main strength giving compositions are tricalcium aluminate $\left(3 \mathrm{CaO} \cdot \mathrm{Al}_{2} \mathrm{O}_{3}\right)$, tricalcium silicate $\left(3 \mathrm{CaO} \cdot \mathrm{SiO}_{2}\right)$ and dicalcium silicate $\left(2 \mathrm{CaO} \cdot \mathrm{SiO}_{2}\right)$. Portland cement contains very little free lime. Almost the entire amount of it is present in the combined state as calcium silicate and calcium aluminate. Portland cement sets to a hard mass on hydration. To hold up the "Flash Set", caused by tricalcium aluminate, the gypsum added as a retarder causes the formation of calcium sulphoaluminate $\left(3 \mathrm{CaO} . \mathrm{Al}_{2} \mathrm{O}_{3} \cdot 3 \mathrm{CaSO}_{4} \cdot 31 \mathrm{H}_{2} \mathrm{O}\right)^{19-21}$.

On account of the setting characteristics and moisture resistance of Portland cement, experimental investigations with Portland cement as an additive were therefore carried out in order to find out its effects on strength and durability of magnesium oxysulphate cement.

\section{Experimental}

Magnesium oxysulphate cement ${ }^{22}$ can be prepared by taking raw materials including commercial grade magnesia $(\mathrm{MgO})^{23}$ of Salem origin, magnesium sulphate (Epson salt, $\left.\mathrm{MgSO}_{4} \cdot 7 \mathrm{H}_{2} \mathrm{O}\right)^{24}$ and dolomite (as an inert filler) ${ }^{25}$, where dolomite reduces thermal shocks in the cement as it absorbs the heat evolved during the exothermic formation of oxysulphate cement.

To study the effects of admixing Portland cement as an additive, following tests have been carried out by taking Portland cement in different proportions in the dry mix (1:2 dry mix, one part by weight of magnesia and 2 parts by weight of dolomite) on some properties of magnesium oxysulphate cement. All experiments were carried out according to IS specifications $^{26}$. 


\section{Results and Discussion}

\section{Setting time}

The effect of Portland cement on setting characteristics of magnesium oxysulphate cement was studied by admixing the additive in the dry mix in varying proportions. Standard procedure according to IS specifications were adopted for standard consistency and initial and final setting periods with the help of Vicat needle apparatus ${ }^{26}$. Results are summarized in Table 1.

Table 1. Effect of Portland cement on setting characterstics of oxysulphate cement.

Conc. of g.s $=25^{\mathrm{O}} \mathrm{Be}$

Volume of g.s. $=70 \mathrm{~mL}$

Temperature $=30 \pm 2{ }^{\circ} \mathrm{C}$

Relative humidity $=>90 \%$
Dry mix composition $=1: 2$

(One part by weight of magnesia:

Two parts by weight of dolomite + additive $)$ Quantity of dry mix $=200 \mathrm{~g}$

\begin{tabular}{cccc}
\hline \multirow{2}{*}{ S.No. } & Dry mix composition, & \multicolumn{2}{c}{ Setting Time } \\
\cline { 3 - 4 } & \% Additive & Initial, min & Final, min \\
\hline 1 & 0 & 20 & 133 \\
2 & 5 & 15 & 210 \\
3 & 10 & 10 & 230 \\
4 & 15 & 5 & 238 \\
5 & 20 & 245 \\
\hline
\end{tabular}

Weathering effects

g.s. $=$ Gauging solution

Investigations were made by recording the weights of all the setting time blocks with different quantities of additive by chemical balance after 24 h, 7 days, 30 days and 45 days. Before that, all the blocks were cured under identical conditions of temperature and humidity. Observations are recorded in Table 2.

Table 2. Effect of Portland cement on weathering characteristics of oxysulphate cement

Conc. of g.s $=25^{\mathrm{O}} \mathrm{Be}$

Volume of g.s. $=70 \mathrm{~mL}$

Temperature $=30 \pm 2{ }^{\circ} \mathrm{C}$

Relative humidity $=>90 \%$
Dry mix composition $=1: 2$

(One part by weight of magnesia:

Two parts by weight of dolomite + additive)

Quantity of dry mix $=200 \mathrm{~g}$

\begin{tabular}{cccccc}
\hline \multirow{2}{*}{ S.No } & Dry mix composition, & \multicolumn{4}{c}{ Weight of blocks in g after } \\
\cline { 3 - 6 } & \% Additive & $24 \mathrm{~h}$ & 7 days & 30 days & 45 days \\
\hline 1 & 0 & 258.870 & 251.163 & 243.322 & 241.440 \\
2 & 5 & 255.040 & 242.020 & 230.350 & 229.930 \\
3 & 10 & 254.740 & 235.100 & 226.280 & 225.920 \\
4 & 15 & 262.430 & 243.130 & 233.500 & 233.070 \\
5 & 20 & 254.250 & 230.000 & 226.350 & 225.980 \\
\hline
\end{tabular}

Moisture ingress (Steam Test)

g.s. $=$ Gauging solution

In order to find the effect of Portland cement on moisture ingress of magnesium oxysulphate cement, setting time blocks with different amounts of additive were exposed constantly to boiling water for at least $30 \mathrm{~h}$ after two months of curing under identical conditions. This test is carried out to ascertain the soundness of the product. Relative water vapor transmissions (moisture ingress) were expressed as a function of time (h) required for the development of cracks in the trial blocks. Less the water vapor transmission more the soundness ${ }^{27,28}$. Observed results are summarized in Table 3. 
Table 3. Effect of Portland cement on moisturizing ingress characteristics of oxysulphate cement.

Conc. of g.s $=25^{\mathrm{O}} \mathrm{Be}$

Volume of g.s. $=70 \mathrm{~mL}$

Temperature $=30 \pm 2{ }^{\circ} \mathrm{C}$

Relative humidity $=>90 \%$
Dry mix composition $=1: 2$

(One part by weight of magnesia

Two parts by weight of dolomite + additive)

Quantity of dry mix $=200 \mathrm{~g}$

\begin{tabular}{cccccccc}
\hline S.No & Dry mix composition, & \multicolumn{5}{c}{ Trial blocks kept in boiling water for } \\
\cline { 3 - 7 }$\%$ Additive & $0-5, \mathrm{~h}$ & $5-10, \mathrm{~h}$ & $10-15, \mathrm{~h}$ & $15-20, \mathrm{~h}$ & $20-25, \mathrm{~h}$ & $25-30, \mathrm{~h}$ \\
\hline 1 & 0 &. E. & N.E. & N.E. & N.E. & $\mathrm{C}$ & ---- \\
2 & 5 & $\mathrm{C}$ & ---- & ---- & ---- & ---- & ---- \\
3 & 10 & $\mathrm{C}$ & --- & --- & --- & --- & --- \\
4 & 15 & N.E & N.E. & N.E. & N.E. & N.E. & N.E. \\
5 & 20 & N.E. & N.E. & N.E. & N.E. & N.E. & N.E. \\
\hline \multicolumn{6}{c}{ g.s. $=$ Gauging solution, } & N.E. $=$ No effect, $C=$ Cracked
\end{tabular}

\section{Compressive Strength}

In order to study the effect of Portland cement on compressive strength of oxysulphate cement, standard cubes of $50 \mathrm{~cm}^{2}(70.6 \mathrm{~mm} \times 70.6 \mathrm{~mm} \times 70.6 \mathrm{~mm})$ were prepared from IS consistency pastes having Portland cement as additive in varying amounts. These cubes were cured for one month under standard conditions and then compressive strength of the trial blocks was determined with the help of compressive strength testing machine as per standard procedure ${ }^{17,26}$. Observations are recorded in Table 4.

Table 4. Effect of Portland cement on compressive strength of oxysulphate cement

\begin{tabular}{lllllll}
$\begin{array}{l}\text { Conc. of g.s }=25^{\mathrm{O}} \mathrm{Be} \\
\text { Volume of g.s. }=200 \mathrm{~mL}\end{array}$ & \multicolumn{2}{l}{$\begin{array}{l}\text { Dry mix composition }=1: 2 \\
\text { (One part by weight of magnesia }\end{array}$} \\
$\begin{array}{c}\text { Temperature }=30 \pm 2{ }^{\mathrm{O}} \mathrm{C} \\
\text { Relative humidity }=>90 \%\end{array}$ & \multicolumn{2}{l}{$\begin{array}{l}\text { Two parts by weight of dolomite } \\
\text { Quantity of dry mix }=565 \mathrm{~g}\end{array}$} \\
\hline $\begin{array}{c}\text { Dry mix } \\
\text { composition }\end{array}$ & $0 \%$ & $5 \%$ & $10 \%$ & $15 \%$ & $20 \%$ \\
\hline $\begin{array}{c}\text { Compressive strength } \\
\mathrm{Kg} / \mathrm{cm}^{2}\end{array}$ & 275 & 270 & 300 & 330 & 360 \\
\hline \multicolumn{4}{c}{ g.s. $=$ Gauging solution }
\end{tabular}

\section{Linear Change}

g.s. $=$ Gauging solution

The effect of Portland cement on linear changes of magnesia cement was studied by preparing wet mixes with different quantities of additive and was filled in standard sized moulds (200 $\mathrm{mm} \times 25 \mathrm{~mm} \times 25 \mathrm{~mm}$ ). These trial beams were kept under $90 \%$ relative humidity and at $30 \pm 20{ }^{\circ} \mathrm{C}$ temperatures for $24 \mathrm{~h}$. Initial length of the beams was determined using micrometer scale. Final lengths were measured after 28 days of curing under identical conditions. Linear changes were studied by the difference between two readings. The lesser the linear change, the greater will be the soundness of the product ${ }^{29}$. Experimental findings are shown in Table 5.

\section{Setting characteristics}

Table 1 reflects the effect of admixing Portland cement in the dry mix in varying proportions on setting characteristics of oxysulphate cement. Initial setting times are found to decrease with increasing additive quantities. Portland cement becomes reasonably hard by moisture absorption (hydration). The reactions involved are the hydration of calcium aluminate and calcium silicate, which change into their colloidal gels. At the same time, some calcium hydroxide and aluminium 
hydroxide are formed as precipitate due to hydrolysis. Calcium hydroxide binds the particles of calcium silicate together while aluminium hydroxide fills the interstices rendering the mass impervious. These reactions are responsible for fast initial setting $(\mathrm{Eq} 1-6)$.

Table 5. Effect of Portland cement on linear changes of oxysulphate cement.

Conc. of g.s $=25^{\mathrm{O}} \mathrm{Be} \quad$ Dry mix composition $=1: 2$

Volume of g.s. $=105 \mathrm{~mL} \quad$ (One part by weight of magnesia

Temperature $=30 \pm 2{ }^{\circ} \mathrm{C} \quad$ Two parts by weight of dolomite + additive $)$

Relative humidity $=>90 \% \quad$ Quantity of dry mix $=300 \mathrm{~g}$

\begin{tabular}{|c|c|c|c|c|}
\hline \multirow{2}{*}{ S.No } & \multirow{2}{*}{$\begin{array}{c}\text { Dry mix composition, } \\
\% \text { Additive }\end{array}$} & \multicolumn{2}{|c|}{ Length of beams, $\mathrm{mm}$} & \multirow{2}{*}{$\begin{array}{l}\text { Change in } \\
\text { Length, } \mathrm{mm}\end{array}$} \\
\hline & & Initial & Final & \\
\hline 1 & 0 & 200.00 & 200.02 & 0.02 \\
\hline 2 & 5 & 200.00 & 199.69 & 0.31 \\
\hline 3 & 10 & 200.00 & 199.68 & 0.32 \\
\hline 4 & 15 & 200.00 & 199.91 & 0.09 \\
\hline 5 & 20 & 200.00 & 199.76 & 0.24 \\
\hline
\end{tabular}

$$
\begin{aligned}
& \text { g.s. }=\text { Gauging solution } \\
& 3 \mathrm{CaO} \cdot \mathrm{Al}_{2} \mathrm{O}_{3}+6 \mathrm{H}_{2} \mathrm{O} \rightarrow 3 \mathrm{CaO} \cdot \mathrm{Al}_{2} \mathrm{O}_{3} \cdot 6 \mathrm{H}_{2} \mathrm{O} \\
& \text { Tricalcium aluminate Hydrated Colloidal Gel of Tricalcium alumiante } \\
& 3 \mathrm{CaO} \cdot \mathrm{SiO}_{2}+\mathrm{H}_{2} \mathrm{O} \rightarrow \mathrm{Ca}(\mathrm{OH})_{2}+2 \mathrm{CaO} \cdot \mathrm{SiO}_{2} \\
& \text { Tricalcium silicate Dicalcium silicate } \\
& 2 \mathrm{CaO} \mathrm{SiO}_{2}+\mathrm{XH}_{2} \mathrm{O} \rightarrow 2 \mathrm{CaO} \cdot \mathrm{SiO}_{2} \cdot \mathrm{XH}_{2} \mathrm{O} \\
& \text { Dicalcium silicate Hydrated Colloidal Gel of Dicalcium silicate } \\
& 3 \mathrm{CaO} \cdot \mathrm{Al}_{2} \mathrm{O}_{3}+6 \mathrm{H}_{2} \mathrm{O} \rightarrow 3 \mathrm{Ca}(\mathrm{OH})_{2}+2 \mathrm{Al}(\mathrm{OH})_{3} \\
& \text { Tricalcium aluminate } \\
& 4 \mathrm{CaO} \cdot \mathrm{Al}_{2} \mathrm{O}_{3} \cdot \mathrm{Fe}_{2} \mathrm{O}_{3}+6 \mathrm{H}_{2} \mathrm{O} \rightarrow 3 \mathrm{CaO} \cdot \mathrm{Al}_{2} \mathrm{O}_{3} \cdot 6 \mathrm{H}_{2} \mathrm{O}+\mathrm{CaO} \cdot \mathrm{Fe}_{2} \mathrm{O}_{3} \\
& \text { Tetracalcium aluminoferrite Hydrated colloidal gel } \\
& \text { of tricalcium aluminate } \\
& 3 \mathrm{CaO} \cdot \mathrm{Al}_{2} \mathrm{O}_{3}+3 \mathrm{CaSO}_{4}+31 \mathrm{H}_{2} \mathrm{O} \rightarrow 3 \mathrm{CaO} \cdot \mathrm{Al}_{2} \mathrm{O}_{3} \cdot 3 \mathrm{CaSO}_{4} \cdot 31 \mathrm{H}_{2} \mathrm{O} \\
& \text { Calcium sulphoaluminate }
\end{aligned}
$$

Final setting periods also show increasing trends with increasing proportions of Portland cement in the dry mix. None of the above factors contribute to the final setting that requires formation of intercrossing system of crystals to give a rocky mass. Increase in final setting can be explained by the fact that Portland cement releases calcium ions in the wet mix and other polymeric anions, which are harmful for the formation of magnesia cement (Eq 7-10). Secondly, Portland cement itself is slow setting cement, which contributes to increase in final setting periods.

$$
\begin{aligned}
& \mathrm{Ca} / \mathrm{MgO}+\mathrm{H}_{2} \mathrm{O} \rightarrow \underset{\mathrm{Ca} / \mathrm{Mg}(\mathrm{OH})_{2}}{\mathrm{CaSO}} \cdot 2 \mathrm{H}_{2} \mathrm{O}+\mathrm{Mg}(\mathrm{OH})_{2} \\
& \mathrm{Ca}(\mathrm{OH})_{2}+\mathrm{MgSO}_{4}+2 \mathrm{H}_{2} \mathrm{O} \rightarrow \mathrm{CaSO}_{4}+\mathrm{ZH}_{2} \mathrm{O} \rightarrow \underset{\mathrm{Ca}(\mathrm{OH})_{2} \cdot \mathrm{YCaSO}_{4} \cdot \mathrm{ZH}_{2} \mathrm{O}}{ } \mathrm{Xalcium} \text { oxysulphate } \\
& \mathrm{XCa}(\mathrm{OH})_{2}+\mathrm{YCaSO}_{4} \\
& 5 \mathrm{Mg}(\mathrm{OH})_{2}+\mathrm{MgSO}_{4}+8 \mathrm{H}_{2} \mathrm{O} \rightarrow \begin{array}{c}
5 \mathrm{Mg}(\mathrm{OH})_{2} \cdot \mathrm{MgSO}_{4} \cdot 8 \mathrm{H}_{2} \mathrm{O} \\
\text { Magnesium oxysulphate } \\
\text { (Strength giving composition) }
\end{array}
\end{aligned}
$$

\section{Weathering characteristics}

Weathering characteristics of Sorel's cement on the incorporation of Portland cement as an additive are obvious from Table 2. Gradual decrease in the weights of the trial blocks is attributable to the evaporation of loosely bound and strongly associated moisture with lapse 
of time. Absorption of carbon dioxide by lime or by any other constituent of Portland cement is not involved at all as there is very little free lime on account of its presence in combined state as calcium silicate and calcium aluminate ${ }^{19}$. Increase in weights at later stages is therefore not observed.

\section{Moisture ingress}

Small additions of Portland cement in the matrix $(5 \%, 10 \%)$ do not contribute to water tightness. This may be due to the erosive effect of active lime and other harmful impurities. Such an effect weakens the structure of magnesia cement. Accordingly, marked decrease in water tightness is quite expected. On increasing the quantities of additive in the mixture $(15 \%, 20 \%)$, water tightness of the product improves gradually on account of the inherent moisture impervious nature of Portland cement. Magnesium oxysulphate, formed in such compositions, remain as strengthening filler (Table 3).

\section{Compressive strength}

Compressive strength data of oxysulphate cement with varying additive proportions are enumerated in Table 4. Increasing trends in compressive strength of the product with increasing quantities of Portland cement in the matrix are noticed. This is explicable by the fact that chances of formation of intercrossing systems of magnesium oxysulphate with calcium oxysulphate and also with calcium and aluminium silicates increase with increasing proportions of the additive. This contributes to increase in mechanical strength.

\section{Linear changes}

Minor contractions (within the experimental limits) in the trial beams are noticed on account of loss of moisture with passage of time. This makes the structure compact. The results are listed in Table 5.

\section{Conclusion}

- Portland cement accelerates initial setting process where as retards final setting process of magnesia cement.

- Water tightness of the product increases with increasing quantities of the additive.

- Incorporation of Portland cement contributes to gain in strength.

- Insignificant contractions are noticed in trial beams on admixing Portland cement in the matrix.

\section{Acknowledgements}

One of the authors (SKS) is very grateful to Dr. V. K. Agarwal, (Chairman) IET Group of Institutions, Alwar for providing him the opportunity to establish a Computational \& Green Chemistry Research Laboratory at IET, Alwar.

\section{References}

1. Brady G S, Materials Hand Book, McGraw Hill, Fifteenth Edition, 2002, 17.

2. Fink G J, Kirk-Othmer Encyclopedia of Chemical Technology, 1935, 3, 435; Taylor H F W, The Chemistry of Cements, Academic Press, New York, 1964.

3. Sorel S T, C R Acad Sci, Paris, 1867, 65, 102.

4. Maravelaki Kalaitzaki P, Moraitov G, Cement Concrete Res., 1999, 29(12),1929.

5. British Cement Association: Different Types of Cements, www.azobuild.com, Article Id 7959, Nov 2006. 
6. See Bacon R, in Growth and Perfection of Crystals, Edited by Doremus, R H, Wiley, New York, 1958, 197; Nabarro F R N and Jackson, P J, ibid., 77.

7. DeWolff P M and Walter-Levy L, Acta Cryst., 1953 6, 40.

8. Brunauer S and Copeland L E, Sci Amer., 1964, 210(4), 81.

9. Jones T P and Mooney B, Nature., 1965, 207, 752.

10. Beaudoin James J, Ramchandran Vangipuram S and Feldman R F, Am Ceram Soc Bull., April 1977, 424.

11. Vangipuram S R, Ralph M P, Baeudoin J and Delgado A H, Handbook of Thermal Analysis of Construction Materials, William Adrew Inc., 2002, 359.

12. Tooper B and Cartz L, Nature, 1966, 211, 64.

13. Mathur R, Chandrawat M P S and Nagpal K C, Research and Industry, Sept 1984, 29, 195.

14. Ramchandran V S and Feldman R F, Cem Concr Res., 1973, 3, 729.

15. Feldman R F and Ramchandran V S, J Am Ceram Soc., 1966, 49, 268.

16. Soroka I and Sereda P J, J Am Ceram Soc., 1968, 51, 337.

17. Beaudoin J J and Ramchandran V S, Cem Concr Res., 1975, 5, 617.

18. Mathur R and Sharma S K, Rasayan J Chem., 2008, 1(3), 620.

19. Kirk R E and Donald F.Othmer, Encyclopedia of Chemical Technology, Second Ed., Vol 2: 5 (P), Vol 4: 5, $690(\mathrm{P})$; Vol 12: 458 (P)

20. Shreve R N, Chemical Process Industries $3^{\text {rd }}$ Ed., 1967, 164.

21. Bogue R H, The Chemistry of Portland Cement, $2^{\text {nd }}$ Ed., Reinhold Publishing Corp, New York, 1955,703

22. Satya Prakash, Madan R D, Modern Inorganic Chemistry, S Chand, New Delhi, 2005, 906.

23. Indian Standard: 1982, 657

24. Indian Standard: 1977, 2730.

25. Indian Standard: 1962, 1760.

26. Indian Standard: 1982, 10132.

27. Chandrawat M P S, Yadav R N and Mathur R, Res \& Ind., March 1994, 39, 18.

28. Gupta Y K, Chandrawat M P S and Yadav R N, Res \& Ind., 1990, 35, 191.

29. Mathur R, Effect of Some Additives on Bonding Characterstics of Magnesium Oxysulphate Cement, 1993, Ph D Thesis, University of Rajasthan, India. 


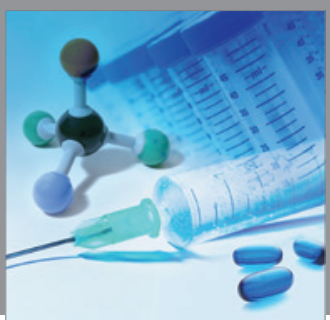

International Journal of

Medicinal Chemistry

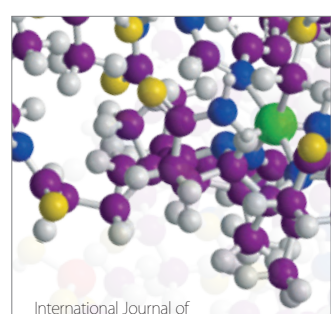

Carbohydrate Chemistry

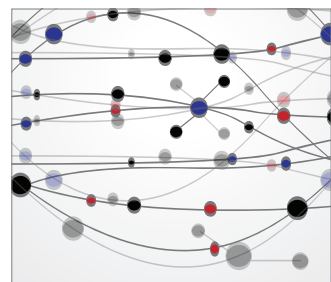

The Scientific World Journal
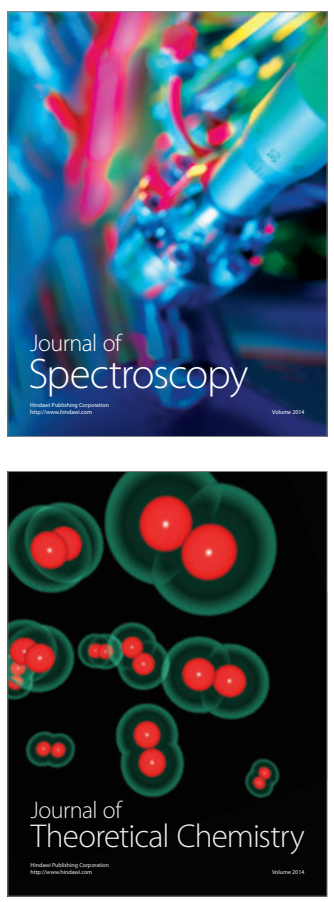
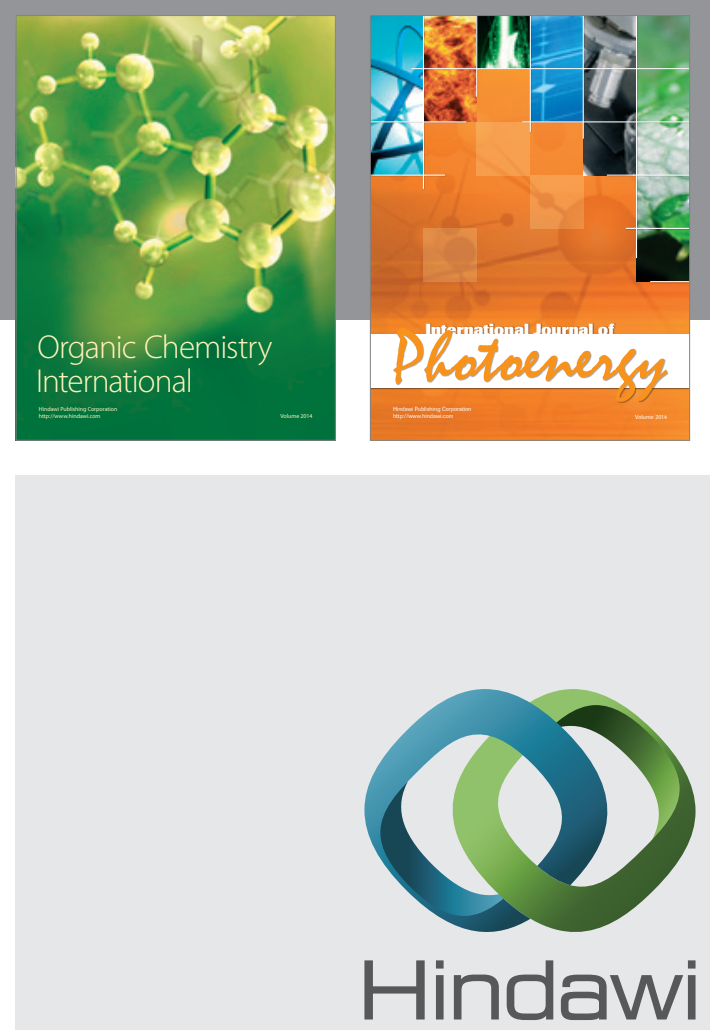

Submit your manuscripts at

http://www.hindawi.com
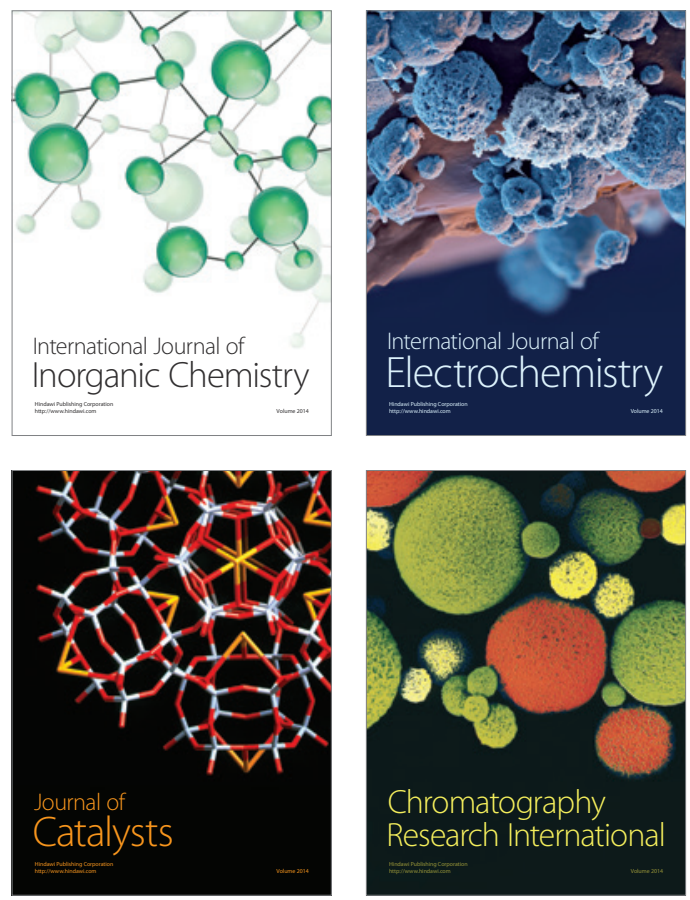
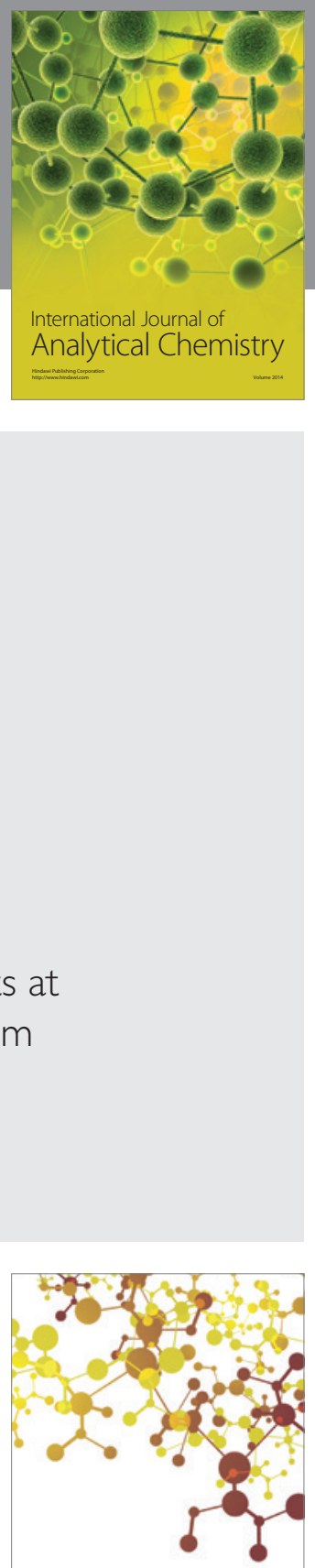

Journal of

Applied Chemistry
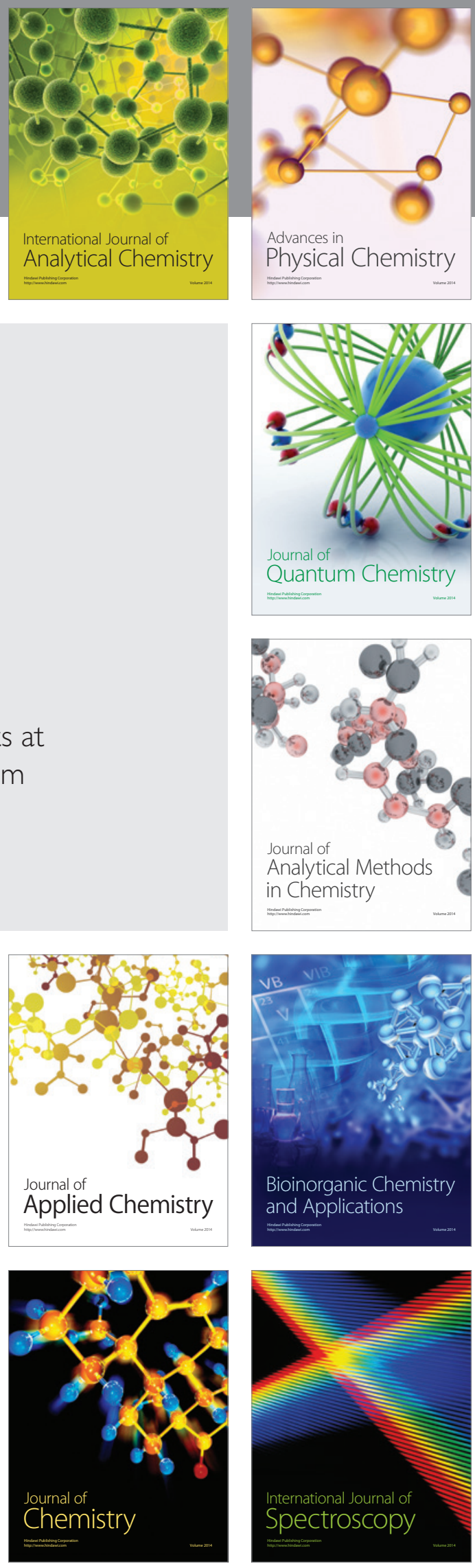